ENTREPRENEURSHIP AND SUSTAINABILITY ISSUES

ISSN 2345-0282 (online) http://jssidoi.org/jesi/

2020 Volume 7 Number 3 (March)

http://doi.org/10.9770/jesi.2020.7.3(72)

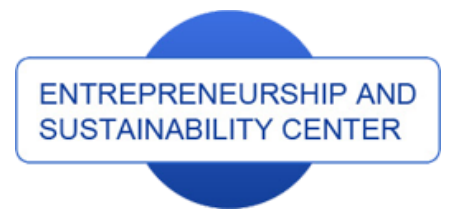

Publisher

http://jssidoi.org/esc/home



Business Support on Your Doorstep

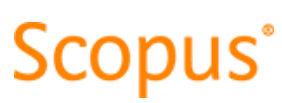 \\ CASPA Scopus' Weboifscence
}

Clarivate

Analytics

\section{CREDITWORTHINESS PLACE IN CREDIT THEORY AND METHODS OF ITS EVALUATION*}

\author{
Aina Caplinska ${ }^{1}$, Manuela Tvaronavičienė ${ }^{2}$ \\ ${ }^{1}$ Department of Sociology and Economy, Faculty of Social Sciences, Daugavpils University, Parades Str.1, Daugavpils, LV- \\ 5401, Latvia \\ ${ }^{2}$ Vilnius Gediminas Technical University, Sauletekio al. 11, Vilnius, Lithuania \\ ${ }^{2}$ Institute of Humanities and Social Sciences, Daugavpils University, Parades Str. 1-421, Daugavpils, LV-5401, Latvia
}

E-mails: ${ }^{1}$ aina.caplinska@gmail.com $;{ }^{2}$ manuela.tvaronaviciene@vgtu.lt.

Received 15 June 2019; accepted 10 January 2020; published 30 March 2020

\begin{abstract}
The authorss regard credit evolution in the economic thought and the notion of borrower's creditworthiness, with a special emphasis on its place in credit theory. In the process of credit theory evolution the authorss singled out three stages of theory development: 1) the naturalist theory of credit that originated within the classical political economy (A. Smith, D. Ricardo) and treated credit as a natural mechanism used by banks to redistribute the material resources in the society; 2) the capital-raising theory of credit that originated in the framework of monetarism (J. Loe, G. Mcleod, J. Shumpeter, F. Friedman, etc.) and is based on the position that credit can set in movement all production factors that are not in use in the country to create wealth and capital; 3) theory of credit regulation that originated under the impact of the depression of 1929-1933 within J. Keins'Canes' theory and justified the significance of credit regulation in economy, emphasizing that it may facilitate economic development also in the period of crisis. Along with the origin of credit theory in economic research literature in the $18^{\text {th }}$ century the term 'borrower's creditworthiness' appeared that was used by A. Smith, J. Keins, N. Bunge, V. Kossinsky, etc. The analysis of definitions of borrower's creditworthiness available in research literature makes it possible for the authorss of the present study to argue that each of the suggested definitions emphasizes 1-2 aspects of creditworthiness without its systemic formulation, taking into account the borrower's ability of receiving, efficiently using, and repaying credit. Hence, the authorss suggest own updated definition of borrower's creditworthiness that is considered to be innovative

\footnotetext{
* This research was partly supported by the project, which has received funding from the European Union's Horizon 2020 research and innovation programme European Research Council (ERC) under the European Union's Horizon 2020 research and innovation programme Marie Sklodowska-Curie Research and Innovation Staff Exchanges ES H2020-MSCA-RISE-2014 CLUSDEVMED (2015-2019) Grant Agreement Number 645730730
}
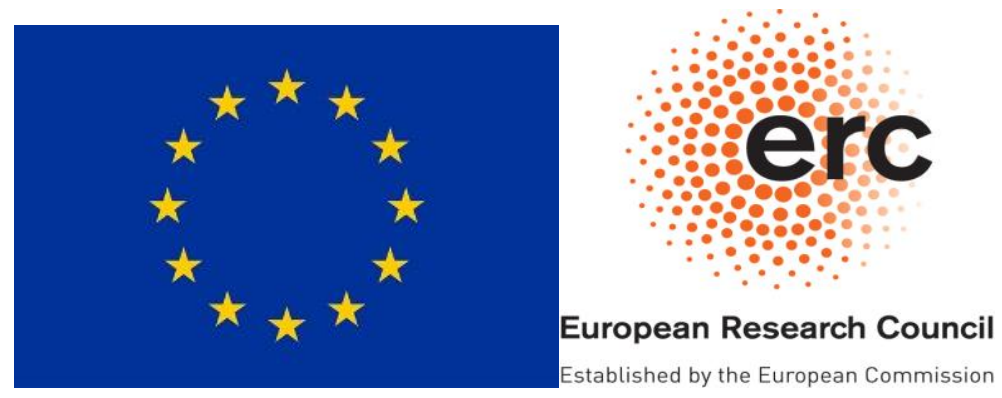


\section{ENTREPRENEURSHIP AND SUSTAINABILITY ISSUES}

ISSN 2345-0282 (online) http://jssidoi.org/jesi/

2020 Volume 7 Number 3 (March)

http://doi.org/10.9770/jesi.2020.7.3(72)

and especially significant in the context of the borrower's long-term development. It must be noted that in the science of economics the assessment of borrower's creditworthiness is based on two methodological paradigms - creditworthiness as absence of bankruptcy and creditworthiness as an ability of efficient use of credit; the authors consider the latter to comply with the conception of a sustainable economic development, thus it must be the basis for selecting methods of assessment of borrower's creditworthiness in the contemporary practice of crediting. The authorss have selected for analysis methods of assessment of borrower's creditworthiness existing in research literature and actually used - rating, prognosis, complex methods - whereof borrower's creditworthiness is calculated by multiplying the chosen indicator values with the weight of their significance in the integral indicator.

Keywords: credit; borrower's creditworthiness

Reference to this paper should be made as follows: Caplinska, A., Tvaronavičienè, M. 2020. Creditworthiness place in Credit Theory and methods of its evaluation, Entrepreneurship and Sustainability Issues, Entrepreneurship and Sustainability Issues 7(3), 2542-2555. http://doi.org/10.9770/jesi.2020.7.3(72)

JEL Classifications: G32, G20, H31, L26, M10

\section{Introduction}

Article entails the analysis of the theoretical and methodological aspects of credit and creditworthiness, the evolution of the respective theories and conceptions in the science of economics as well as comparison of various methodological approaches to the assessment of borrower's creditworthiness.

Credit has a special position in the system of economic relations; it functions as an independent economic category. Hence, both economy on the whole and individual legal and physical persons have an opportunity to meet their economic and personal needs by overcoming the limits of financial resources. Credit relations allow an enterprise on the account of additional financing to expand production, enlarge its resources as well as accelerate the achievement of the set goals. On the whole credit may facilitate the economic potential of the society.

There is no single credit theory in macroeconomics. The evolution of credit and credit relations is manifested in the development of credit theories. Taking into consideration that researchers have long ago taken up studies of credit relations, the development of credit theory took an especially significant qualitative leap in the period of developed capitalism when the role of credit and banks in economics became much more important. History proves that credit theory is transition from its essence, functions, rules of movement to the role of an instrument of economic development in the mechanism of state regulation.

According to N. Bunge, credit theory developed under the influence of two major conditions: first, under the influence of the basic ideas of the dominant economic school, second, that of the activities of the existing credit institutions. The development of credit theories was also affected by various kinds of economic crises as well as socio-economic conditions predominant in the epoch of the respective researchers' lives (Bunge, 1852).

Theoretical accounts and justifications of credit occur in research conceptions of different trends and schools. In the course of time it is possible to differentiate three main credit theories:

- the naturalist theory of credit;

- the capital-raising theory of credit;

- theory of credit regulation.

Research on credit relations reveals diverse methodological approaches to credit existing in theory and practice. This pluralism is conditioned by the peculiarities of each stage of economic system development: economic, social, and political processes in national and world economics, different methodological approaches of the representatives of various schools and trends of economic theory. To summarize, there are three theoretical approaches to credit: 


\section{ENTREPRENEURSHIP AND SUSTAINABILITY ISSUES}

ISSN 2345-0282 (online) http://jssidoi.org/jesi/

2020 Volume 7 Number 3 (March)

http://doi.org/10.9770/jesi.2020.7.3(72)

1) credit is a negative beginning having no impact on economy; credit is a 'great invention' having a huge impact on economic development;

2) credit has a moderate role and is related only to the redistribution of resources.

These three approaches to the functional role of credit in economy testify not only to the diversity of judgement but also to the contradictions of many standpoints in each of these approaches.

Credibility affects financial security of companies (Dubauskas, 2012; Stasytytè and Aleksienè, 2015; Smrčka et al., 2016; Belás et al., 2017; Caplinska, Ohotina, 2019; Caurkubule et al., 2020; Chehabeddine, Tvaronavičienė, 2020), improvement of business environment development and of entrepreneurship (Ohotina et al., 2018; Lincényi, Čársky, 2020; Vigliarolo, 2020; El Idrissi et al., 2020; Tvaronavičienè et al., 2020).

The credit policies to be adjusted by taking into account the effects of the policy measures on the economic growth of the country and its sustainable development (Tvaronavičiené, 2014; Mentel \& Brożyna, 2015; Tamulevičienè, 2016; Korauš et al., 2017.).

According to the authorss of the present research, credit initially has positive aspects and it may also have negative ones that are rather subjective than objective expressions of it, e.g. using credit inadequately to its purpose that testifies to low creditworthiness of the borrower.

\section{The notion of borrower's creditworthiness and its position in credit theory}

The notion of creditworthiness (creditability, creditworthiness, credibility) appeared in the literature of economics in the $18^{\text {th }}$ century. It was used in research works by A. Smith (Smith, 1970), J. Canes (Keyns, 1993), N. Bunge (Bunge, 1852) and V. Kossinsky (Kossinsky, 1903). In Latvian economic environment the notion of creditworthiness was introduced rather recently. After regaining independence along with the development of entrepreneurship and crediting there appeared borrower's inability to pay the credit back to the lender and problems related to this.

Customer's creditworthiness in the practice of world banks has been and still is one of the main objects of assessment of the usefulness and kinds of credit relations. Contemporary economists' opinions as to the definition of the notion 'creditworthiness' may be split into several groups. One of the groups unites authorss who pay special attention to the moral image of the customer.

Already at the end of the $19^{\text {th }}$ century N. Bunge in his work "Credit Theory" mentions the expression of the French banker J. Loe: "By expressing trust we pay attention to their (customers') honesty - it makes us sure that we will not be deceived; their mastery - it gives us hope that they have not been mistaken in their calculations; their occupation - this lets us expect certain interest" (Bunge, 1852). Also according to E. Bregel, "the first and the most important credit condition is that the person seeking the opportunity of crediting would not seem untrustworthy as to his/her moral traits" (Bregel, 1955).

Nowadays this approach to borrower's creditworthiness that pays special attention not only to the moral image of the customer but to that of both parties is being revitalized; this is proved by the fact that creditworthiness is more and more often defined in Western research literature by the notion of trustability. According to the research produced in the USA that focuses on the most trustworthy crediting partners in the country, the main reasons for which crediting partners trust one another are "their ability to constantly respect the strategic interests of the partner, sometimes even at the expense of one's own short-term interests" (Peppers, 2011). The authors of the doctoral thesis considers that this approach is based first of all on the treatment of the crediting process partners as economic partners with common interests. 


\section{ENTREPRENEURSHIP AND SUSTAINABILITY ISSUES}

ISSN 2345-0282 (online) http://jssidoi.org/jesi/

2020 Volume 7 Number 3 (March)

http://doi.org/10.9770/jesi.2020.7.3(72)

The second group entails those authorss who believe that creditworthiness is most closely connected with efficiency in appropriating the borrowed assets. According to A. Bobileva, creditworthiness of enterprise is related to its abilities of efficient use of the borrowed assets (Bobileva, 2003). Many economists support the idea that creditworthiness rests on the borrower's ability to raise enough financial means to return the loan. Hence, V. Kossinsky emphasized: "Creditworthiness is changed by the conditions that guarantee that capital will be reproduced and will not be lost" (Kossinsky, 1903).

Hence, economists belonging to this group, regarding the issue of giving credit, as the major prerequisite emphasize borrower's abilities to get income right from the credit assets that would let the borrower both repay the loan and derive profit for further development. The authors of the doctoral thesis holds that this approach is based on the paradigm of borrower's development that means that enterprise is creditworthy when it works and constantly develops, not when it just exists and has not gone bankrupt (this according to the authors is the paradigm of borrower's creditworthiness as surviving).

There is also the third group of economists who identify the notion 'creditworthiness' with the notion 'paying capacity'. Hence, A. Achkasov defines creditworthiness of the economic subject as its ability of due settlement of all fixed date payments securing a normal production process on the account of its own assets in the way that makes it possible without serious financial shocks to mobilize in the shortest time period a sufficient amount of money assets to settle all fixed liabilities in relation to different creditors (Achkasov, 1994).

According to the authors this definition equalizes the notions 'creditworthiness' and 'paying capacity'. Latvian scientist I. Kalis also defines creditworthiness of an enterprise as its ability of due settlement of its debts (Kalis, 2004).

The authors holds that the above mentioned definitions that are conditionally attributed to group three are of a single aspect. The major part of definitions are based on the main and in most cases the sole criterion that determines the level (class) of creditworthiness as the borrower's financial and economic situation that is determined according to the balance of incomes and expenditures.

The authors would also attribute the approach of International credit rating agencies to the third group of definitions of creditworthiness, as these agencies assess the borrower's creditworthiness on the basis of its ability to settle liabilities in the past and future (Black's Law Dictionary, 1990).

As concerns the main document of Basel Committee on Banking Supervision - "International Convergence of Capital Measurement and Capital Standards" (Basel II), it operates with the notion default risk that is closer to the notion of borrower's paying capacity than of creditworthiness and accentuates only the interests of bank as a participant of the process of crediting to get back credit money in due time and in total amount (Basel II, 2004).

The notion of default is based on the borrower's surviving paradigm instead of the borrower's development paradigm, closer to which is exactly the borrower's creditworthiness in the sense of the second group representatives mentioned above. In scientific literature the notion 'default' is related to the content of credit risk that is usually understood as the fact of failure of the borrower to settle its liabilities (Romanova, 2009).

Latvian scientists suggest an interpretation of borrower's creditworthiness that opposes the approach of the above described group and emphasizes that the notion of creditworthiness is often confused with the notion "credit repayment capacity' noting that "the bank is more interested in the customer's capacity to pay the credit back" (Zelgalve, Petrovska, 2004). This approach was further developed in the work by R. Rupeika-Apoga and E. Zelgalve (Rupeika-Apoga, Zelgalve, 2009). 
The theoretical analysis of the notion 'creditworthiness' must be carried out on the basis of system approach taking into consideration the complexity of this notion and the presence of numerous different aspects (Heylighen, 1992; Hitchins, 2003). Attempts to provide a complex theoretical account for the notion 'creditworthiness' unites economists in group four.

The important notion of capacity is regarded in the definition provided by G. Kirisyuk and V. Lyahovsky: "The essence of the category 'creditworthiness' is the borrower's actual judicial and financial and economic situation, on the basis of the assessment whereof the bank makes the decision about starting (developing) or terminating credit relations with the borrower" (Kirisyuk, Lyahovskiy, 1999).

Interpreting the borrower's creditworthiness within a complex approach, a whole of certain factors is usually taken into consideration, including the borrower's legal capacity and capacity for the execution of credit transaction; its moral image and reputation; the presence of guarantee; the borrower's ability to make profit in general and especially from the credit assets.

This diversity of definitions of creditworthiness is accountable for by first ad foremost the evolution of this notion, and it reflects different stages of it.

Retrospective analysis of the notion of creditworthiness leads to the conclusion that this economic category is very closely connected with the culture of crediting on the whole that, in turn, reflects the level of the development of the market on which creditor and borrower work.

Therefore, according to the authors, the evolution of the notion 'creditworthiness' takes place mostly under the impact of the economic environment of the functioning of the parties of credit relations, i.e. it depends on national market economy development and integration in the world market.

The authors hold that the reason for difference in definitions is that they in fact reflect different stages of the financial market functioning from the period of formation to the contemporary state of development.

In the figure below the authors try to systematize the above considered conceptions of borrower's creditworthiness taking into consideration the aspect of the prerequisites and conditions of their origin. 
ENTREPRENEURSHIP AND SUSTAINABILITY ISSUES

ISSN 2345-0282 (online) http://jssidoi.org/jesi/

2020 Volume 7 Number 3 (March)

http://doi.org/10.9770/jesi.2020.7.3(72)



\section{PRECONDITIONS AND CONDITIONS OF THE ORIGIN OF CONCEPTIONS}


Figure Error! No text of specified style in document.. Conceptions of borrower's creditworthiness, preconditions and conditions of their origin

Source: figure produced by the authorss.

Proceeding from the results of the research produced, the authors of the doctoral thesis suggests the following definition of borrower's creditworthiness that complies with the contemporary situation: it is borrower's judicial and financial capacity to attract credit assets as well as willingness and ability under the conditions of uncertainty and specific branch, regional, and individual peculiarities to pay back the received credit (with interest) in the time specified in the agreement with the precondition that all will be paid back from the added value of the credit money. This definition reflects the manifold (complex) character of the aspects of the notion 'creditworthiness' and entails the following:

- the financial state of the potential borrower and the existence of adequate credit guarantee;

- reputation of the enterprise management;

- belonging of enterprise to a particular sector;

- the economic and political state of the borrower's enterprise;

- the enterprise capacity of efficient work in order to get added value from credit assets. 
ENTREPRENEURSHIP AND SUSTAINABILITY ISSUES

ISSN 2345-0282 (online) http://jssidoi.org/jesi/

2020 Volume 7 Number 3 (March)

http://doi.org/10.9770/jesi.2020.7.3(72)

\section{Methods of the assessment of borrower's creditworthiness}

Methods of assessing borrower's creditworthiness may be classified according to the distribution of the applied approaches in two groups: approaches that are based on classification models and those based on the complex analysis of the borrower (see figure 2).

Classification models provide an opportunity to divide borrowers into classes, models of prognosis differentiate them depending on the probability of bankruptcy, rating models differentiate borrowers into classes depending on the category determined by means of the calculable financial coefficient and the significance level attributed to them. The balance of enterprise is topical for the elaboration of the assessment model of any borrower's creditworthiness as they all are based on the balance data. Nowadays credit rating is a popular notion widely used in assessing borrower's creditworthiness. Credit rating is assessment or rating elaborated by credit management companies or rating agencies that denotes a certain stage of enterprise's creditworthiness, and this stage usually expresses the maximum credit limit of the partner of transaction. Basel Committee on Banking Supervision recommends using a standardized approach for setting rating or an approach based on internal rating system. In the case of standardized approach, rating is determined by external organizations, e.g. international rating agencies - Standard\&Poor's, Fitch IBCA, Moody's Investors Service. Internal rating system based approach is worked out in banks.

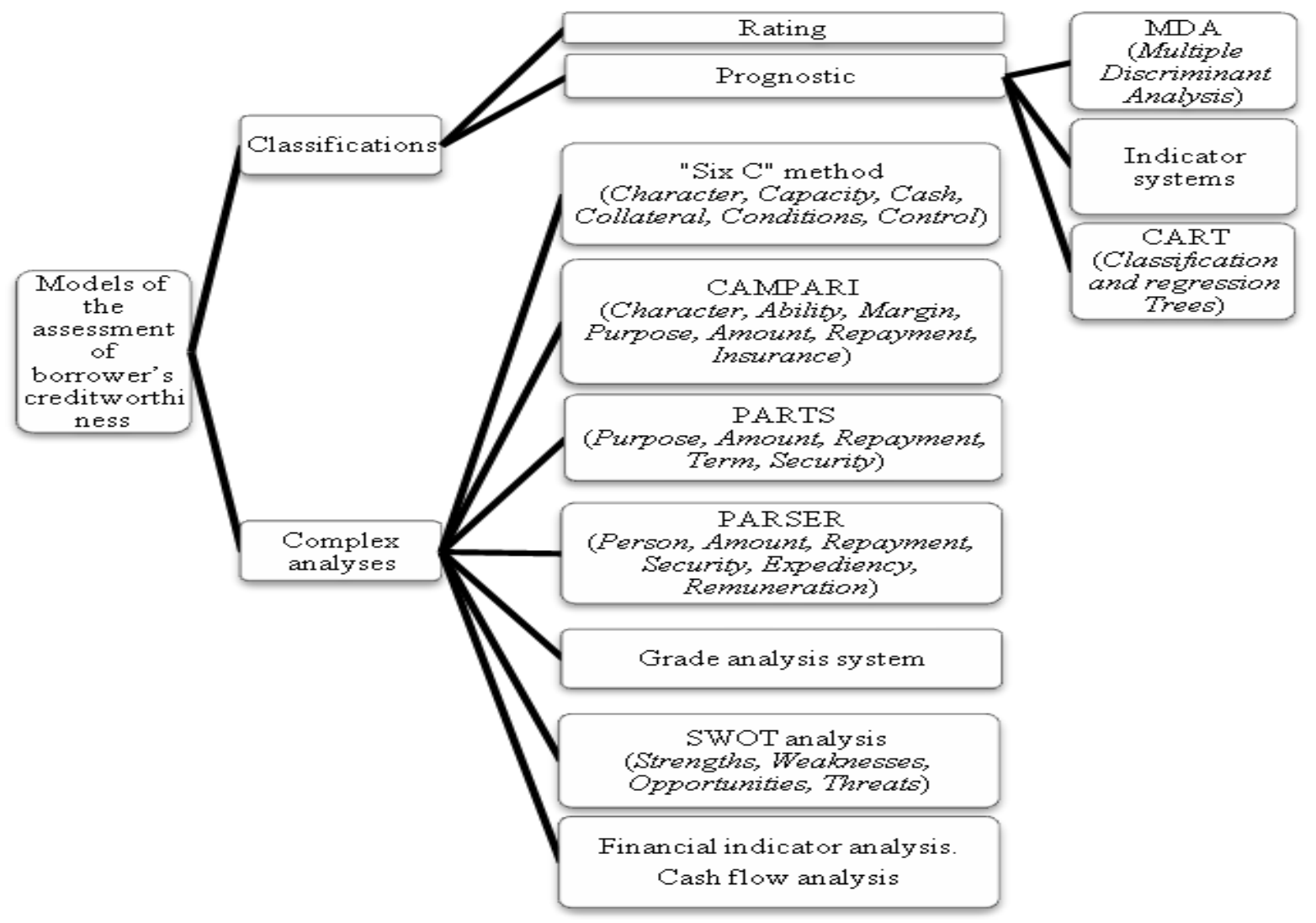

Figure 2. Classification of the models of assessment of borrowers' creditworthiness 


\section{ENTREPRENEURSHIP AND SUSTAINABILITY ISSUES}

ISSN 2345-0282 (online) http://jssidoi.org/jesi/

2020 Volume 7 Number 3 (March)

http://doi.org/10.9770/jesi.2020.7.3(72)

Source: figure produced by the authorss

Credit scoring is a modification of rating assessment; it is a technical means suggested in the 1940s by the US scientist D. Durand for choosing borrowers in accordance with consumer credit (Durand, 1941). Credit scoring differs by using in the formula of rating assessment partial point assessment of indicator instead of its value. The use of this method, according to the authors of the present research, requires taking into consideration several problems:

1. necessity to carefully select financial indicators (indicators characterizing different spheres of the borrower's functioning, to provide more complete account of its state);

2. importance of justifying the border value of indicators (in this country it is rather complicated to carry out such an approach as there is a lack of information on the actual state and levels of these indicators in Latvian economy);

3. necessity to justify coefficients of significance for each group of indicators according to the sphere of action of the particular borrower;

4. locating the deviations in border spheres, thus classifying borrowers in different groups;

5. producing rating assessment, the levels of indicators are taken into account only in relation to optimal values that correspond to certain set normatives, yet the degree of their execution or failure of execution is not considered;

6. financial coefficients reflect the state of matters in the past based on the data of remnants;

7. the estimated coefficients reflect only separate spheres of action;

8. in the system of estimated coefficients, numerous factors are ignored, e.g. the borrower's reputation, perspectives, peculiarities of market condition, perspectives of the produced and to be sold products and capital investment.

Models of prognoses based on statistical methods are used for the assessment of potential borrowers' creditworthiness. Financial analytics have always tried to predict the bankruptcy of an enterprise on the basis of the values of numeral coefficients or some kind of other collected indicators. The understanding of the notion 'bankruptcy' is especially important because in works by many economists models of the so-called bankruptcy prognosis occur. Depending on the source of information, the notion of bankruptcy has a twofold meaning. In one case it is used as a synonym for the notion 'insolvency' while in other it is the solution of the situation of insolvency.

W. Beaver in the 1960s for the first time systematized coefficients reflecting with a certain probability the possibility of enterprise bankruptcy (Beaver, 1966, 1968). The dynamic of these coefficients testified to the features of bankruptcy of an enterprise. Proceeding from the analysis of the tendency of change of financial indicators and using the critical value scale, the enterprise under analysis could be classified within a certain group of risk.

The multiple discriminant analysis makes use of the discriminant function that takes into account some parameters (regression coefficients) and factors characterizing the financial state of the borrower (including financial coefficients). Regression coefficients are estimated by producing statistical data processing of companies that have either gone bankrupt or survived in a particular period of time. If the -assessment is closer to the indicator of an average bankrupt company, then, on condition that its state continues deteriorating, it will go bankrupt. If company managers and the bank make effort to eradicate the financial problems, it will probably not go bankrupt. Thus, -assessment is a signal warning of the possible bankruptcy of the enterprise. The use of this model needs rather representative sampling of enterprises across diverse spheres and sizes. It is made more complicated by the fact that it is not always possible to find a sufficient number of enterprises having gone bankrupt in a certain sphere in order to calculate the regression coefficient. 


\section{ENTREPRENEURSHIP AND SUSTAINABILITY ISSUES}

ISSN 2345-0282 (online) http://jssidoi.org/jesi/

2020 Volume 7 Number 3 (March)

http://doi.org/10.9770/jesi.2020.7.3(72)

The most widespread is the model by E. Altman including the following indicators: correlation of asset turnover and the sum of assets, reinvestable profit and the sum of assets, stock market value and the borrower capital, profit from selling and the sum of assets, gross profit (profit before interest and tax deduction) and the sum of assets. Classifying an enterprise in a particular group of safety is produced on the basis of -index values of E. Altman's model.

Taking into consideration that Altman's model was elaborated on the basis of the data of the USA enterprises in the period from 1946 to 1965 (Altman, 1971), its identical use in an economy of another country is rather limited. Therefore researchers in other countries produced new models adjusting them to the economies of their countries, e.g. Chesser's model (Chesser, 1974), R. Taffler's and H. Tisshaw's model (Taffler, 1984; Taffler, Tisshaw, 1977), Springate's four factor model (Springate, 1978), Fedotova's two factor model (Fedotova, 1995), and Saifulin's and Kadykov's five factor model (Saifulin, Kadikov, 2003).

Latvian researcher R. Zhuka's (Žuka, 2005) work shows that Altman's models cannot be mechanically transferred and used under the conditions of Latvian marker, while the researcher of the University of Latvia, R. Shneidere proved that Altman's formula holds true only with the enterprises of some spheres in Latvia (Šneidere, 2009). A model of creditworthiness matching Latvian conditions was worked out by a group of scientists of Riga Technical University. According to them, this model ignores peculiarities of spheres and the model of prognosis of the probability of bankruptcy is elaborated on the basis of a small sampling of enterprises.

The model CART (Classification and Regression Trees) (Sinki, 1994) may be used for classifying credits. It is a non-parametrical model the main advantages whereof are the opportunity of wide application, simplicity of understanding and calculating it, though it is formed by complex statistical methods. In a 'classification tree' borrowers are placed on a certain 'branch' depending on the values of the selected coefficients; next there are smaller offshoots from each branch depending on the further indicated coefficients. Precision of classification by using this model equals approximately $90 \%$.

However, the use of mathematical models prevents taking into consideration the impact of quality factors when banks give credits. These models let bank credit experts just partially make a conclusion of the possibility of giving credit. Deficiencies of classification models are their closure on quantitative factors, free choice of the quantitative indicator system, high sensitivity to the initial improbability of data, and heaviness in the use of interbranch and branch statistical data. Within the complex analysis models it is possible to join the quantitative and qualitative characteristics of the borrower. For instance, in the banking practice of the USA the 'six C' rule is used based on the use of six major principles of crediting denoted by the words beginning with $\mathrm{C}$ - Character, Capacity, Cash, Collateral, Conditions, Control (Altman et al, 1998).

The essence of the analysis of the borrower's creditworthiness according to the principles of crediting of CAMPARI method is sequential singling out the main factors determining the customer's action from the application for credit and the financial documents enclosed with it, assessing them more particularly after meeting the customer in person. The name of the method CAMPARI is formed from the first letters of the following words: Character - customer's reputation and characteristics, Ability - of credit repayment, Margin profitability, Purpose of the credit, Amount of the credit, Repayment terms, Insurance against the risk of credit repayment failure.

In British banks the key word conveying the demands for giving credit is PARTS: P (Purpose) - of the credit, A (Amount) - justification of the credit sum, R (Repayment) - possibility of repayment, $\mathrm{T}($ Term $)$ - of credit, $\mathrm{S}$ (Security) - of credit repayment, or PARSER: P (Person) - customer's characteristics, reputation, A (Amount) justification of the credit sum, R (Repayment) - possibility of repayment, S (Security) - assessment of credit guarantee, E (Expediency) - credit expediency, R (Remuneration) - recompense to the bank (the rate of interest) for the risk of giving credit (Hollander, 1979). 


\section{ENTREPRENEURSHIP AND SUSTAINABILITY ISSUES}

ISSN 2345-0282 (online) http://jssidoi.org/jesi/

2020 Volume 7 Number 3 (March)

http://doi.org/10.9770/jesi.2020.7.3(72)

Along with the above stated methods, SWOT analysis can be used to locate the strengths and weaknesses, opportunities and threats of the enterprise or the financed project. SWOT analysis is used for the assessment of the advantages and problems of the enterprise's internal and external factors:

- strengths - the enterprise characteristics that may help attain the set goal;

- weaknesses - the characteristics that may impede reaching the set goal;

- opportunities - the external factors that may help attain the set goal;

- threats - the external factors that may impede reaching the set goal.

Complex methods for the assessment of borrowers' creditworthiness are used by many commercial banks, yet they are not polished well enough and make a poor use of mathematical apparatus. The main drawbacks of the methods of the assessment of borrowers' creditworthiness nowadays, according to the authors of the present research, are as follows:

- subjectivity - rather often the decisions taken by credit specialists are based on their intuition and personal experience;

- rigidity and instability - the assessment quality is an incidental entity that cannot be improved or made worse and it depends on the expert's opinion and preferences;

- lack of a system of instruction, knowledge exchange, and requalification - before becoming a highly qualified professional, knowledge must be accumulated by way of gaining sufficient experience in the sphere;

- a limited number of the regarded credit applications depending on the available human physical resources.

\section{Conclusions}

A group of economists who identify the notion of creditworthiness with the notion of solvency or capacity of credit repayment. Another group of economists are united by attempts at providing a complex theoretical account of the The notion of borrower's creditworthiness originated and developed within credit theory that provided different interpretations of credit and its role in economy - starting with naturalist formulations of credit that are insignificant for economic development up to the present-day interpretation emphasizing the regulating role of credit in economy.

Economists provide diverse definitions of the notion of creditworthiness and their opinions fall in several groups. One group entails authorss paying special attention to the moral image of the borrower and mutual trust of bank and borrower. Another group unites authorss who consider that creditworthiness is most closely related to the efficiency of uptaking the appropriations. There is also notion 'creditworthiness'. This diversity of definitions may be explained mainly by the evolution of this notion and reflects several stages of its formation. The analysis of the notion of creditworthiness shows that this economic category is very closely related to the culture of crediting in general that in turn is the reflection of the development level of the market where creditor and borrower work together. Therefore, according to the authors, the evolution of the notion 'creditworthiness' happens mainly in economic environments of the functioning of creditors and borrowers.

In the research literature on economy there are rather many definitions of borrower's creditworthiness, yet the authors considers that almost all of these definitions lack the element of systematic approach that would regard this notion from all aspects: capacity of credit attracting, capacity of due repayment of credit, as well as that of efficient use of credit resources.

On the basis of the research produced by the authors, her formulation of borrower's creditworthiness at the contemporary stage of credit relations is as follows: it is borrower's judicial and financial capacity to attract credit assets as well as willingness and ability under the conditions of uncertainty and specific branch, regional, and 


\section{ENTREPRENEURSHIP AND SUSTAINABILITY ISSUES}

ISSN 2345-0282 (online) http://jssidoi.org/jesi/

2020 Volume 7 Number 3 (March)

http://doi.org/10.9770/jesi.2020.7.3(72)

individual peculiarities to pay back the received credit (with interest) in the time specified in the agreement making profit also for one's development from the credit resources.

Methods of the assessment of borrower's creditworthiness are manifold, yet they are mainly based on multiplying the value of certain financial indicators by the weight of their indicator significance in the resulting indicator. This resulting indicator depends on the character of the method: that is the borrower's credit rating when using rating methods, the probability of borrower's bankruptcy in methods of prognosis, and borrower's creditworthiness assessment in complex methods.

Studying the borrower's creditworthiness, the authorss came to the conclusion that, though it characterizes borrower, in the actual situation is basically urgent for lender-banks; however, successful and long-term mutually profitable credit relations between an enterprise and a bank are grounded on the precondition that borrower's creditworthiness should become the focus of both the bank and the enterprise. This would mean in practice that, in the process of assessment of borrower's creditworthiness and creation of bank credit portfolio, the enterprise and the bank must be cooperation partners with common interests, instead of being opponents in the field of crediting.

\section{References}

Achkasov A.L. 1994. Aktivnyie operatsii kommercheskih bankov. [Active Operations of Commercial Banks]. Moskva:Konsalt-Bankir.

Altman E., Caonetle J., Naarayanan, P. 1998. Managing credit risk. New York.

Belás, J., Mišanková, M., Schönfeld, J., Gavurova, B. 2017. Credit risk management: financial safety and sustainability aspects. Journal of Security and Sustainability Issues, 7(1), 79-93. https://doi.org/10.9770/jssi.2017.7.1(7)

Bentley Capital Ventures. 2017. What Is A Dun \& Bradstreet PAYDEX Score And How Does It Work For Me. Available on the Internet: http://bentleycapitalventures.com/2017/10/what-is-a-dun-bradstreet-paydex-score-and-how-does-it-work-for-me/

Black‘s Law Dictionary. 6th. ed. 1990. New York:West Publishing.

Bregel, E.Ya.1955.Ssudnyiy kapital ikredit. [Loan Capital and Credit]. Moskva: Gosfinizdat.

Briede, I. 2004. Banku finanšu pakalpojumi [Banking financial services]. Rīga: Biznesa augstskola Turība, p.116.

Bunge, N.H.1852. Teoriya kredita. [Credit risks]. Kiev.

Čaplinska, A. 2011. Aizṇēmēju kredītspēja un bankas kredītportfeḷa veidošanas problēmas Latvijā. [Borrowers' Solvency and Problems of Formation of Bank Loan Portfolio in Latvia]. Rēzekne: RA izdevniecība.

Caplinska, A., Ohotina, A. 2019. Analysis of financial literacy tendencies with young people. Entrepreneurship and Sustainability Issues, 6(4), 1736-1749. https://doi.org/10.9770/jesi.2019.6.4(13)

Caurkubule, Zh. L., Kenzhin, Zh. B. Bekniyazova, D.S., Bayandina, G.D., Dyussembekova, G. S. 2020. Assessment of competitiveness of regions of the Republic of Kazakhstan. Insights into Regional Development, 2(1), 469-479. http://doi.org/10.9770/IRD.2020.2.1(6)

Chehabeddine, M., Tvaronavičienè, M. 2020. Securing regional development. Insights into Regional Development, 2(1), 430-442. http://doi.org/10.9770/IRD.2020.2.1(3)

Domenico Curcio, I. G. 2009. Bank loans pricing and Basel II: a multi-period risk-adjusted. Banks and Bank Systems, 4(4), 66-75.

Dubauskas, G. 2012. Sustainable growth of the financial sector: the case of credit unions. Journal of Security and Sustainability Issues, 1(3), 159-166. https://doi.org/10.9770/jssi/2012.1.3(1) 


\section{ENTREPRENEURSHIP AND SUSTAINABILITY ISSUES}

ISSN 2345-0282 (online) http://jssidoi.org/jesi/

2020 Volume 7 Number 3 (March)

http://doi.org/10.9770/jesi.2020.7.3(72)

Dun \& Bradstreet, Inc. 2011. A Guide to D\&B's U.S. Ratings and Scores, Business credit reports. Available on the Internet: https://www.businesscreditreports.com/documents/guide-to-d-b-ratings-scores.pdf

Džondžua, M. 2007. Parādu atgūšana, Kredītu pārvaldības tehnoloǵija un psiholoǵija.[Technology and Psychology of Loan Management]. Rīga: Biznesa augstskola Turība.

El Idrissi, N. E. A., Ilham Zerrouk, I., Zirari, N., Monni, S. 2020. Comparative study between two innovative clusters in Morocco and Italy. Insights into Regional Development, 2(1), 400-417. http://doi.org/10.9770/IRD.2020.2.1(1)

Enciklopedija Ekonomista. 2019. Bankovskije operacii. [Bank Operations]. Available on the Internet: http://www.grandars.ru/student/bankovskoe-delo/ocenka-kreditnogo-riska.html

Enciklopedija Ekonomista. 2019. Ocenka kreditnogo riska [Assessment of Credit Risks]. Available on the Internet: http://www.grandars.ru/student/bankovskoe-delo/ocenka-kreditnogo-riska.html

Fair Isaac Corporation. 2018. Learn About The FICO Score and its Long History. Available on the Internet: http://www.fico.com/en/products/fico-score\#overview

FKTK. 2001. Kredītriska pārvaldīšanas ieteikumi. Latvijas Vēstnesis 169 [Latvian Bulletin 169]. Available on the Internet: https://www.vestnesis.lv/ta/id/55790

Grēviņa, R. 2000. Ekonomikas skaidrojošā vārdnīca. [Explanatory Dictionary of Economics]. Rīga: Izdevniecība Zinātne.

Heylighen, F.1992. Cybenetics and Systems, in Trappl R.(Ed.). Singapore: World Science, 3-10.

Kālis, I. 2004. Finanšu menedžments [Financial Management]. Rīga: Latvijas Universitate.

Keyns, Dzh. M. 1993. Izbrannyie proizvedeniya. [Selected Works]. Moskva: Ekonomika.

Keyns, Dzh. M. 1994 Upravlenie finansami v kommercheskih bankah. [Financial Management at Commercial Banks]. Moskva: Cotalaxy.

Kirisyuk, G.M., Lyahovskiy, V.S.1999. Otsenka bankom kreditosposobnosti zaemschika. [Banks' Assessment of Borrowers' Solvency]. Dengi i kredit, (11), 34-52.

Korauš, A., Simionescu, M., Bilan, Y., Schönfeld, J. 2017. The impact of monetary variables on the economic growth and sustainable development: case of selected countries. Journal of Security and Sustainability Issues, 6(3), 383-390. https://doi.org/10.9770/jssi.2017.6.3(5)

Kudinska, M. 2005. Komercbanku riski un to atbilstība pašu kapitālam. [Risks for Commercial Banks and their Compliance with Equity]. Rīga: Datorzinību centrs, 296 p.

Kudinska, M. 2008. Kreditēšana.[Credit Activities]. Rīga: SIA tipogrāfija Pērse, 126 p.

Kutuzova, O. 2012. Finanses un kredīts. [Finance and Credit]. Rīga: Biznesa augstskola Turība.

Lektsii po mikroekonomike. 2018. Teorii kredita Dzhona Lo i Adama Smita. [Theories of Loan and Banking by John Lock and Adam Smith]. Available on the Internet: http://newinspire.ru/lektsii-po-dkb/teorii-kredita-dzhona-lo-i-adama-smita-1769

Leon, Pedro Cieza de. 2018. Seno rakstu bibliotēka. [Library of ancient writings].

Lincényi, M., Čársky, J. 2020. Policy trusts in public policy in the Slovak Republic. Insights into Regional Development, 2(1), 456-468. http://doi.org/10.9770/IRD.2020.2.1(5)

Marx, K. 1983. Capital: A Critique of Political Economy (I). London: Lawrence \& Wishart.

Mentel, G., Brożyna, J. 2015. Compatibility of market risk measures. Journal of International Studies, 8(2), 52-62. https://doi.org/10.14254/2071-8330.2015/8-2/5 


\section{ENTREPRENEURSHIP AND SUSTAINABILITY ISSUES}

ISSN 2345-0282 (online) http://jssidoi.org/jesi/

2020 Volume 7 Number 3 (March)

http://doi.org/10.9770/jesi.2020.7.3(72)

Ohotina, A., Lavrinenko, O., Ignatjeva, S., Lonska, J. 2018 a. Socio-economic security as a determinant of regional differences in the investment climate in the region, Journal of Security and Sustainability Issues, 7(3), 427-438. https://doi.org/10.9770/jssi.2018.7.3(5)

Romānova, I. 2009. Iekšējo reitingu sistēma aizṇēmēju kredītriska novērtēšanai. [Internal Rating System for Assessing Borrowers' Credit Risk]. Rīga: SIA Izglītības solii.

Rurāne, M. 2006. Finanšu menedžments [Financial Management]. Rīga: Rīgas Starptautiskā ekonomikas un biznesa administrācijas augstskola, $383 \mathrm{p}$.

Saksonova S. 2010. Komercdarbības finansēšana. [Financing of Commercial Activities]. Rīga: Latvijas Universitāte.

Schupeter J. A. 1983. The Theory of Economic Development. New Jersey: New Brunswich.

Smith A. 1970. The Wealth of Nations (1). London: Dent, New York: Dutton.

Smrčka, L., Plaček, J., Schönfeld, J., Louda, L. 2016. Insolvenční řízení. Praha: Professional Publishing.

Šneidere, R. 2009. Finanšu analīzes metodes uzṇēmuma maksātnespējas prognozēšanai [ Methods of Financial Analysis for Forecasting a Company's Insolvency]. Rīga: Lietišḳās informācijas dienests, 232 p.

Springate, G.L.V. 1978. Predicting The Possibility of failure in a Canadian Firm: A Discriminant Analysis. Simon Fraser University.

Stasytytė, V., Aleksienè, L. 2015. Operational risk assessment and management in small and medium-sized enterprises, Business: Theory and Practice, 16(2), 140-148. http://dx.doi.org/0.3846/btp.2015.568

Taffler, R.J. 1984. Empirical Models for the Monitoring of UK Corporations. Journal of Banking and Finance, 8(2), $199-227$.

Taffler, R.J., Tisshaw, H. 1977. Going, going, Gone-Four Factors Which Predict Accountancy.

Tamulevičienė, D. 2016. Methodology of complex analysis of companies’ profitability. Journal of Security and Sustainability Issues, 4(1), 53-63. http://dx.doi.org/10.9770/jesi.2016.4.1(5)

The Basel Committee on Banking Supervision. 2006. International Convergence of Capital Measurement and Capital Standards: A Revised Framework Comprehensive version. Available on the Internet: https://www.bis.org/publ/bcbs128.pdf

Tvaronavičienė, M., Baublys, J., Raudeliūnienė, J., Jatautaite, D. Chapter 1 - Global energy consumption peculiarities and energy sources: Role of renewables, Editor(s): Manuela Tvaronavičienė, Beata Ślusarczyk, Energy Transformation Towards Sustainability, Elsevier, 2020, Pages 1-49, ISBN 9780128176887, https://doi.org/10.1016/B978-0-12-817688-7.00001-X

Vigliarolo, F. 2020. Economic phenomenology: fundamentals, principles and definition. Insights into Regional Development, 2(1), 418429. http://doi.org/10.9770/IRD.2020.2.1(2)

Zelgalve E., Petrovska N. 2004. Kredītspējas analīze un novērtēšana. [Creditworthiness analysis and evaluation]. Rīga:LU akadēmiskais apgāds.

\section{Acknowledgement}




\section{ENTREPRENEURSHIP AND SUSTAINABILITY ISSUES}

ISSN 2345-0282 (online) http://jssidoi.org/jesi/ 2020 Volume 7 Number 3 (March)

http://doi.org/10.9770/jesi.2020.7.3(72)

This research was partly supported by the project, which has received funding from the European Union's Horizon 2020 research and innovation programme European Research Council (ERC) under the European Union's Horizon 2020 research and innovation programme Marie Sklodowska-Curie Research and Innovation Staff Exchanges ES H2020-MSCA-RISE-2014 CLUSDEVMED (2015-2019) Grant Agreement Number 645730730


Aina CAPLINSKA Dr.oec., She is a docent at the Department of Sociology and Economics at Daugavpils University, Latvia. Her research interests are finance and credit, banking.

ORCID ID: https://orcid.org/0000-0003-3099-7641

Manuela TVARONAVIČIENÉ is professor at Vilnius Gediminas Technical University of Lithunia. She is national head of European Union's Horizon 2020 research and innovation programme European Research Council (ERC) under the European Union's Horizon 2020 research and innovation programme Marie Sklodowska-Curie Research and Innovation Staff Exchanges ES H2020-MSCARISE-2014 CLUSDEVMED (2015-2019) Grant Agreement Number 645730730. ORCID ID: ORCID ID: https://orcid.org/0000-0002-9667-3730

Copyright (C) 2020 by authors(s) and VsI Entrepreneurship and Sustainability Center This work is licensed under the Creative Commons Attribution International License (CC BY). http://creativecommons.org/licenses/by/4.0/ 